\title{
Effects of exposure of callus cells of two wheat varieties to silver nanoparticles and silver salt $\left(\mathrm{AgNO}_{3}\right)$
}

\author{
A. Barbasz ${ }^{1}$ B. Kreczmer ${ }^{1}$ M. Oćwieja ${ }^{2}$
}

Received: 7 September 2015/Revised: 30 November 2015/Accepted: 8 February 2016/Published online: 20 February 2016

(C) The Author(s) 2016. This article is published with open access at Springerlink.com

\begin{abstract}
Metal nanoparticles significantly affect the physiological properties of plants, e.g., seed germination, growth and metabolism. In the present study, the toxic effects of silver nanoparticles (AgNPs) and silver ions were studied on callus cells of two varieties of wheat (Triticum aestivum L.): stress tolerant-Parabola; stress sensitiveRaweta. Stress induced by silver particles or ions $(0,20$, $40,60 \mathrm{ppm}$ ) was investigated using different parameters such as morphological characteristics, lipid peroxidation and mobilization of defense system which was determined by analyzing the activity of antioxidant enzymes, glutathione (GSH) and proline contents. Microscopic observations revealed deformation of cells after treatment by sol of higher silver concentrations. An increase in malondialdehyde content in both studied varieties was observed. Tested varieties showed an increased proline content in the silver-treated cells. There was no effect of silver on the superoxide dismutases activity, while the activity of catalase was significantly decreased. The changes in the activity of peroxidases in both varieties were opposite. The highest content of intracellular GSH was noticed at a concentration of $20 \mathrm{ppm}$ of both AgNPs and silver ions. The presented results demonstrate a significant similarity of the effects caused by the studied stressors: silver nanoparticles and silver ions. The results characterized the
\end{abstract}

Communicated by Z Miszalski.

\footnotetext{
A. Barbasz

anna.barbasz@op.pl

1 Institute of Biology, Pedagogical University, Podchorążych 2, 30-084 Cracow, Poland

2 Jerzy Haber Institute of Catalysis and Surface Chemistry, Polish Academy of Sciences, Niezapominajek 8, 30-239 Cracow, Poland
}

mechanism of action of nanosilver on wheat callus: morphology disorder, damage to cell membranes, severe oxidative stress and in consequence intensification of production of non-enzymatic antioxidants.

Keywords Wheat $\cdot$ Callus $\cdot$ Silver nanoparticles $\cdot$ Silver ions $\cdot$ Oxidative stress

\section{Introduction}

For several years, nanotechnology has increasingly boldly entered various areas of life, from industry and food to cosmetics and medicine (Kokura et al. 2010; Singh et al. 2008; Tiede et al. 2008) Nanoparticles are considered to be particles of size smaller than $100 \mathrm{~nm}$, which have new properties that are different compared to the particles of the same substance of macro size. The production of metal nanoparticles consists of chemical or physical processes. A controlled process allows for the synthesis of monodisperse nanoparticles of similar shape. The synthesis of NPs often requires the use of toxic substances, which necessitate very accurate machining of the remains of the post-reaction sols and use of additional substances to prevent, inter alia, aggregation of particles (Huang and Yang 2005). A lot of attention is being paid to "green synthesis", a process which is much more environmentally friendly. In such a process, bacteria, yeast, fungi, algae and vascular plants (mainly metallophytes) are exploited (Iravani 2011; Raveendran et al. 2003). Metal nanoparticles may be formed in living organisms by reduction of metal ions absorbed as a soluble salt (Harris and Bali 2008; Bali and Harris 2010). The physical and chemical properties of metal nanoparticles determine their way of interacting with living organisms. They are known to have antimicrobial, 
antifungal and therapeutic properties. Nowadays, silver nanoparticles (AgNPs) have gained great popularity in many areas of life. They are used primarily as antibacterial agents (Marambio-Jones and Hoek 2010) as well as components of drug delivery system or tissue imaging (Godin et al. 2010; Kohl et al. 2011; Kreuter and Gelperina 2008; Meng et al. 2010). The widespread use of nanoparticles exposes all organisms on contact with them. The mechanism that allows transfer of nanoparticles through the cell wall and cell membrane is still not well understood. Nevertheless, it is known that metal nanoparticles can significantly affect cell components. Studies of the impact of AgNPs on the cells of higher organisms showed a reduction of mitochondrial function, cell membrane damage and oxidative stress causing cell injury (Arora et al. 2008; Barbasz et al. 2015; Gorczyca et al. 2015).

The metabolism of plants under stress conditions is biochemically characterized as an increase in the formation of reactive oxygen species (ROS) (Elstner and Osswald 1994; Foyer and Noctor 2000). ROS produced in excess under stress conditions can react with proteins, lipids and DNA molecules, resulting in a number of metabolic disorders, destruction of cell membranes and in consequence cell death (Miller et al. 2010; Lushchak 2011). The defense system against ROS is based on the ascorbate, glutathione, alpha-tocopherol or enzymatic scavengers such as superoxide dismutase (SOD), peroxidases (POX) and catalase (CAT) (Asada 1992; Noctor and Foyer 1998). The toxicity of the nanoparticles may be associated with the possible release of toxicants from their surface, such as metal ions or residues after synthesis (Franklin et al. 2007; Navarro et al. 2008).

In the current work, we aimed at studying the influence of AgNPs on wheat cells. Wheat is a widely cultivated plant exposed to a variety of pathogens. Crop plant protection is an important part of agriculture. So far, the risk of AgNPs has not been fully characterized. Several studies have shown that exposure to metal nanoparticles significantly affected plants physiology, for example seed germination, growth, and metabolism (Table 1). Most of the studies have focused on identifying the effect of metal nanoparticles on the seedlings or mature plants; however, the mechanism of nanoparticle action at the cellular level has still not been thoroughly elucidated.

AgNPs used for the presented experiments were produced by the chemical reduction of silver ions by the natural polyphenolic reducer: tannic acid. Tannic acid contains glucose esterified by gallic acid in the central core, and because of this specific structure it has a stabilizing effect on metal nanoparticles (Dadosh 2009; Dutta and Dolui 2011; Sivaraman et al. 2009, 2010). AgNPs synthesized using tannic acid have unique properties, as presented in our prior studies about its antibacterial activity against selected strains of Escherichia coli and its cytotoxic activity against human cells (Kujda et al. 2015; Barbasz et al. 2015). It is still not known whether the toxicity to living organisms resulted from AgNPs themselves or associated with the release of silver ions from the particles ${ }^{6}$ surface. AgNPs were found to reduce plant growth, photosynthesis and chlorophyll production (Miao et al. 2009). Silver ions released from the surface of silver nanoparticles may inhibit respiratory enzymes and induce oxidative stress by ROS generation (Kim et al. 2007; Pal et al. 2007). Therefore, to determine "what is more cytotoxic-silver nanoparticles or silver ions" here, similarly as in other papers, $\mathrm{AgNO}_{3}$ was chosen for experiments (Foldbjerg et al. 2011; Kim et al. 2009; Navarro et al. 2008).

As a plant material the callus cells were chosen. This type of cells, thanks to their unique properties, allows determining the direct interaction between the test agent and plant cell defense mechanisms. Two varieties of spring wheat (Triticum aestivum L.), tolerant to oxidative stress (Parabola) and a sensitive one (Raweta), were used for callus cell culturing. The differences between the effects of highly purified, stable and well-characterized AgNPs and silver ions on the metabolism of wheat callus cells were discussed.

\section{Materials and methods}

\section{Preparation of silver nanoparticles}

Silver nanoparticles sols were prepared according to the modified Sivaraman's method using tannic acid as a reducing agent (Sivaraman et al. 2009). Silver nitrate $\left(\mathrm{AgNO}_{3}\right)$ was dissolved in distilled water at room temperature to get a silver ion concentration of $1 \mathrm{mmol} \mathrm{dm}^{-3}$. $10 \mathrm{~cm}^{3}$ of $0.6 \mathrm{mmol} \mathrm{dm} \mathrm{dm}^{-3}$ aqueous solution of tannic acid (previously filtered through $0.22 \mu \mathrm{m}$ Millipore filters) was added to $350 \mathrm{~cm}^{3}$ stirred silver precursor. The $\mathrm{pH}$ of the solution was adjusted with ammonia to a value of 9 . The reaction mixture immediately became yellow, but stirring was continued for $60 \mathrm{~min}$. To remove unreacted ions, the obtained sol was washed with deionized water using a stirred membrane filtration cell (Millipore, model 8400) with a cellulose membrane (Millipore, NMWL:100 kDa). The washing procedure was repeated until the conductivity of the filtrate stabilized at $8-10 \mu \mathrm{S} \mathrm{cm}^{-1}$ and $\mathrm{pH}$ at 5.5-5.8.

\section{Techniques of nanoparticles characterization}

The silver nanoparticles concentration in the suspension was determined using a densiometer Anton Paar, type DMA5000M, according to the procedure described 
Table 1 Toxicity of metal nanoparticles to higher plants

\begin{tabular}{|c|c|c|c|}
\hline Nanoparticle types & Plant & Effects & References \\
\hline \multirow[t]{5}{*}{ Silver nanoparticles AgNPs } & Allium сера & $\begin{array}{l}\text { Increasing mitotic index in root tip cells, } \\
\text { cell wall disintegration }\end{array}$ & $\begin{array}{l}\text { (Kumari et al. } \\
\text { 2009) }\end{array}$ \\
\hline & Lolium multiflorum & Inhibition of seedling growth & $\begin{array}{l}\text { (Yin et al. } \\
\text { 2011) }\end{array}$ \\
\hline & $\begin{array}{l}\text { Phaseolus radiates, Sorghum } \\
\text { bicolor }\end{array}$ & & $\begin{array}{l}\text { (Lee et al. } \\
\text { 2012) }\end{array}$ \\
\hline & Triticum aestivum & & $\begin{array}{l}\text { (Vannini et al. } \\
\text { 2014) }\end{array}$ \\
\hline & & Inhibition of the development of roots & $\begin{array}{l}\text { (Gorczyca et al. } \\
\text { 2013) }\end{array}$ \\
\hline $\begin{array}{l}\text { Aluminum oxide }\left(\mathrm{nAl}_{2} \mathrm{O}_{3}\right) \text {, } \\
\text { silicon dioxide }\left(\mathrm{nSiO}_{2}\right) \text {, } \\
\text { magnetite }\left(\mathrm{nFe}_{3} \mathrm{O}_{4}\right) \\
\text { and zinc oxide }(\mathrm{nZnO})\end{array}$ & Arabidopsis thaliana & $\begin{array}{l}\text { Toxic effect on seed germination, root elongation, } \\
\text { and number of leaves dependent on the kind of } \\
\text { nanoparticles and their size }\end{array}$ & $\begin{array}{l}\text { (Lee et al. } \\
\text { 2010) }\end{array}$ \\
\hline $\begin{array}{l}\mathrm{Fe}_{3} \mathrm{O}_{4}, \mathrm{TiO}_{2} \text { and carbon } \\
\text { nanoparticles }\end{array}$ & Cucumis sativus & $\begin{array}{l}\text { Reduction in root growth, seed germination, root } \\
\text { elongation }\end{array}$ & (Mushtaq 2011) \\
\hline $\mathrm{Cu}$ nanoparticles & Elodea densa & $\begin{array}{l}\text { Enhanced lipid peroxidation, } \\
\text { Increasing of SOD and CAT activity }\end{array}$ & $\begin{array}{l}\text { (Nekrasova } \\
\text { et al. 2011) }\end{array}$ \\
\hline $\mathrm{CuO}$ nanoparticles & Landolita punctata & $\begin{array}{l}\text { Decrease of chlorophyll in comparison } \\
\text { to soluble } \mathrm{Cu}^{2+}\end{array}$ & (Shi et al. 2011) \\
\hline $\mathrm{CuO}$ nanoparticles & $\begin{array}{l}\text { Raphanus sativus, Lolium perenne, } \\
\text { Lolium rigidum }\end{array}$ & DNA damage, plant growth inhibition & $\begin{array}{l}\text { (Atha et al. } \\
\text { 2012) }\end{array}$ \\
\hline $\begin{array}{l}\mathrm{CuO} \text { nanoparticles, } \mathrm{ZnO} \\
\text { nanoparticles }\end{array}$ & Cucumis sativus & $\begin{array}{l}\text { Reduction of plant biomass, increase of SOD, } \\
\text { CAT and POD activity in plant root tissue }\end{array}$ & $\begin{array}{l}\text { (Kim et al. } \\
\text { 2012) }\end{array}$ \\
\hline
\end{tabular}

previously (Oćwieja et al. 2011). UV-Vis spectra of silver nanoparticle sol and tannic acid solutions were recorded with Shimadzu UV-1800 spectrometer (data not shown).

The sizes and morphology of silver particles were determined by scanning electron microscopy (JEOL JSM-7500F) working in transmission mode. Samples for this examination were prepared by dispersing a drop of the silver colloid on a copper grid and then covering by carbon film. Independently, AFM pictures of silver nanoparticles deposited on polyelectrolyte (PAH)-covered mica (Oćwieja and Adamczyk 2014) were registered by the NT-MDT Solver Pro instrument equipped with the SMEN SFC050L scanning head. Imaging was done in semicontact mode using a composite probe possessing a silicon body, polysilicon levers and silicon high-resolution tips. The average values of the particle size, polydispersity and stability of suspensions were determined by dynamic light scattering (DLS) measurements (ZetaSizerNano ZS apparatus from Malvern Instruments). Electrophoretic mobility of nanoparticles at controlled conditions obtained from ZetaSizerNano ZS allowed to determine their zeta potential.

\section{Cell culture}

To obtain calli, immature embryos isolated from the seeds of spring wheat (T. aestivum L.), stress-tolerant Parabola and stress-sensitive Raweta, were used. The stress tolerance of these genotypes was confirmed in previous studies (Grzesiak et al. 2013; Filek et al. 2012). Embryos were sterilized in $70 \%$ ethanol for $1 \mathrm{~min}$, and then in $10 \%$ solution of bleaching agent "Domestos" for $10 \mathrm{~min}$. They were rinsed in sterile water and placed on Petri dishes containing Murashige and Skoog (MS) medium (1962) supplemented with $2.4-\mathrm{D}\left(2 \mathrm{mg} \mathrm{dm}^{-3}\right)$ to receive undifferentiated calli (Filek et al. 2009). Then $1 \mathrm{~g}$ of calli was transferred into $20 \mathrm{~cm}^{3}$ MS media containing AgNPs or $\mathrm{AgNO}_{3}$ at concentrations $(20,40,60 \mathrm{ppm})$ and into the medium without additional supplementation and adopted as a control. The silver (particles and ions) at concentrations used in the experiments was also toxic to human cells cultured in vitro (Barbasz et al. 2015). The culture flasks were placed in a circular shaker in a growth chamber, kept at $28^{\circ} \mathrm{C}$ in the dark. After $24 \mathrm{~h}$ of in vitro culturing in such conditions, cytological, biochemical analyses and microscopic observations were made. The microphotographs were made with an inverted microscope set Delta Optical IB 100 with a digital camera HDCE-X5.

\section{Determination of lipid peroxidation}

The degree of lipid peroxidation was determined according to Dhindsa et al. (1981). About $1 \mathrm{~g}$ of calli was 
homogenized in $0.5 \%$ trichloroacetic acid (TCA) and, after centrifugation at $19,000 \times g, 0.5 \mathrm{~cm}^{3}$ of the supernatant was mixed with $2.5 \mathrm{~cm}^{3}$ of $0.5 \%$ thiobarbituric acid (TBA) in $20 \%$ TCA. The mixture was boiled for $30 \mathrm{~min}$ and malondialdehyde (MDA) concentration, as the indicator of lipid peroxidation, was determined spectrophotometrically at $\lambda=532 \mathrm{~nm}$ at room temperature, corrected for non-specific background by subtracting the absorbance at $\lambda=600 \mathrm{~nm}$. The MDA concentration was calculated using the molar extinction coefficient of $155 \mathrm{mM}^{-1} / \mathrm{cm}^{-1}$.

\section{Proline concentration}

The content of proline was determined spectrophotometrically according to the method described by Bates et al. (1973). $1 \mathrm{~g}$ of calli was homogenized in $3 \mathrm{~cm}^{3}$ of $3 \%$ aqueous sulfosalicylic acid and centrifuged at $1000 \times g .0 .5 \mathrm{~cm}^{3}$ of supernatant was added to $1 \mathrm{~cm}^{3}$ of $1 \%$ ninhydrin in $60 \%$ acetic acid and the samples were incubated for $20 \mathrm{~min}$ at $100{ }^{\circ} \mathrm{C}$. After cooling, the reaction mixture was extracted with $3 \mathrm{~cm}^{3}$ toluene and vortex shaken. The absorbance was measured at $\lambda=525 \mathrm{~nm}$ using toluene as a blank sample. The proline content was calculated from the calibration curve.

\section{Enzyme assays}

Approximately, $1 \mathrm{~g}$ of calli was homogenized in a $0.05 \mathrm{M}$ phosphate buffer (pH 7.2) containing $0.1 \mathrm{mmol} \mathrm{dm}^{-3}$ EDTA and $0.1 \%$ bovine serum albumin. The homogenate was centrifuged for $10 \mathrm{~min}$ at $10,000 \times g$. To remove low molecular weight compounds, the supernatant was dialyzed for $8-12 \mathrm{~h}$ in dialysis bags (SIGMA) immersed in phosphate buffer $\left(0.05 \mathrm{~mol} \mathrm{dm}^{-3}, \mathrm{pH} 7.0\right)$ at $4{ }^{\circ} \mathrm{C}$.

Total superoxide dismutases activity [SOD; EC 1.15.11] was assayed according to spectrophotometric cytochrome method by McCord and Fridovich (1969). The reaction mixture consisted of phosphate buffer ( $\mathrm{pH}$ 7.2), $0.1 \mathrm{mmol} \mathrm{dm}{ }^{-3}$ EDTA, $0.1 \mathrm{mmol} \mathrm{dm}{ }^{-3}$ cytochrome $\mathrm{C}$ and $0.1 \mathrm{mmol} \mathrm{dm}^{-3}$ xanthine. Subsequently, xanthine oxidase and the supernatant were added. Absorbance measurements were conducted for $2 \mathrm{~min}$ at $\lambda=550 \mathrm{~nm}$. It is assumed that the unit of activity ( $1 \mathrm{U}, 1 \mathrm{U}$ of cytochrome) corresponds to the amount of enzyme which causes $50 \%$ inhibition of the reduction of cytochrome $\mathrm{C}$ at $25{ }^{\circ} \mathrm{C}$.

The activity of the catalase [CAT; EC 1.11.16] was quantified spectrophotometrically by measuring the kinetics of $\mathrm{H}_{2} \mathrm{O}_{2}$ decomposition (Aebi 1984). The supernatant was added to $0.5 \mathrm{~cm}^{3}$ of $0.054 \mathrm{~mol} \mathrm{dm}^{-3} \mathrm{H}_{2} \mathrm{O}_{2}$ and $1.8 \mathrm{~cm}^{3}$ of $0.05 \mathrm{~mol} \mathrm{dm}^{-3}$ phosphate buffer (pH 7.0). The absorbance was measured for $2 \mathrm{~min}$ at $\lambda=240 \mathrm{~nm}$ at room temperature. For the unit of enzyme activity, a decrease in absorbance within 1 min was adopted.
Measurements of total peroxidase activity [POX; EC 1.11.19] were performed spectrophotometrically according to the modified method of Lück (1962). The amount of products of oxidation of p-phenylenediamine (pPD) in the presence of $\mathrm{H}_{2} \mathrm{O}_{2}$ was determined. The assay mixture contained $0.05 \mathrm{~cm}^{3}$ of $1 \%$ solution of $\mathrm{pPD}, 2 \mathrm{~cm}^{3}$ of phosphate buffer $\left(0.05 \mathrm{~mol} \mathrm{dm}{ }^{-3}\right)$ and $0.05 \mathrm{~cm}^{3}$ of enzyme extract. To initiate the reaction, $0.05 \mathrm{~cm}^{3}$ of $0.03 \mathrm{~mol} \mathrm{dm}^{-3} \mathrm{H}_{2} \mathrm{O}_{2}$ was added and the absorbance at wavelength of $\lambda=460 \mathrm{~nm}$ was measured for $2 \mathrm{~min}$.

All measurements were carried out using a Thermoscientific UV-Vis spectrophotometer.

The activity of the studied enzymes was expressed relative to the protein content in the supernatant. Protein assessment was done by the method of Bradford (1976) using BSA as the standard.

\section{GSH analysis}

The reduced glutathione was determined using the Ellman method (1958). Approximately, $0.75 \mathrm{~g}$ of samples was homogenized in $1.5 \mathrm{~cm}^{3}$ of $0.1 \mathrm{mmol} \mathrm{dm} \mathrm{dm}^{-3}$ phosphate buffer (pH 7.4) containing $10 \mathrm{mmol} \mathrm{dm}^{-3}$ EDTA. The supernatants were deprotonized by adding $0.075 \mathrm{~cm}^{3}$ of $50 \%$ trichloroacetic acid (TCA). Subsequently, the samples were centrifuged at $12,000 \times g$ for $10 \mathrm{~min}$ at $4{ }^{\circ} \mathrm{C}$. Then, $0.1 \mathrm{~cm}^{3}$ of supernatant was mixed with $0.8 \mathrm{~cm}^{3}$ of phosphate buffer (pH 8.2) and $0.1 \mathrm{~cm}^{3}$ of $6 \mathrm{mmol} \mathrm{dm}^{-3}$ DTNB. After 2 min absorbance at $\lambda=412 \mathrm{~nm}$ was measured and the level of GSH was determined from the calibration curve. Values were expressed as $\mu$ moles of GSH per $\mathrm{mg}$ of protein. The total protein concentration was detected according to the method of Bradford (1976) using BSA as the standard.

\section{Statistical analysis}

All biochemical analyses were repeated three times and averaged $( \pm \mathrm{SE})$. All the data were subjected to analysis of variance. The significances between the means were assessed using the SAS ANOVA procedure. The data were analyzed by Duncan's multiple range test and $t$ test at $p<0.05$ using PC SAS 8.0. The statistical tests were run using STATISTICA 10.0. software.

\section{Results}

The procedure for obtaining nanoparticles included a very thorough purification of sol from the post-reaction remains. To achieve quantitative information about the cytotoxicity of silver nanoparticles, the obtained colloidal suspension was characterized using various physicochemical techniques 
(Barbasz et al. 2015). The concentration of AgNPs in purified sol amounted to $330 \mathrm{ppm}$. The size, distribution and shape of nanoparticles were determined by atomic force microscopy (AFM) and transmission electron microscopy (TEM) (Fig. 1). Both techniques revealed a nearly spherical shape and a similar size of AgNPs. The size of single nanoparticle was defined as an average of two perpendicular maximal particle axes. The distribution of particle sizes was presented on the histogram (number of particles in the diameter range). The average size of AgNPs equals $17 \pm 5 \mathrm{~nm}$.

Observations of cells by optical microscopy showed morphological changes of treated cells. It has been found that with increasing concentration of nanoparticles or silver ions, the cells became shorter and "swollen". This effect was observed after treatment with AgNPs at concentrations greater than or equal to $40 \mathrm{ppm}$ and with silver salt at the highest concentration (60 ppm) (Fig. 2).

Treatment with AgNPs or silver ions caused a significant increase in MDA content in both tested varieties. It was found that at the highest concentration of AgNPs (60 ppm), the level of MDA in Parabola increased 1.5-fold, while after treatment with $60 \mathrm{ppm}$ of $\mathrm{AgNO}_{3}$ it increased about twice, as compared to the control sample (Fig. 3a). Lipid peroxidation in a sensitive variety (Raweta) was not statistically different after treatment with AgNPs and silver ions at the highest concentrations. In this case, the MDA level increased about 1.9 times relative to the not treated cells (Fig. 3b).

An increase in proline (a marker of osmotic stress) content in silver-treated cells was observed for both varieties (Fig. 4). Nanoparticles or silver ion application at the highest tested concentration resulted in nearly threefold increase in the proline level. However, this increase was smaller for sensitive wheat variety (Raweta).

The activity of antioxidant enzymes (expressed by protein content) for the Parabola variety was similar for cells treated with AgNPs and silver ions. There was no effect of the addition of silver on SOD activity, while the activity of POX and CAT decreased (Table 2). For cells of the sensitive wheat variety (Raweta), an increase in SOD activity was recorded regardless of the stressor type (Table 2). After treatment of cells with silver ions at a concentration of $60 \mathrm{ppm}$, the POX activity increased by nearly $50 \%$ (relative to the control). It was found that CAT activity significantly decreased (by about $95 \%$ ) in both tested varieties after AgNP or silver ion application.

To explore the relationship between oxidative stress and cytotoxicity of AgNPs, the content of intracellular antioxidant GSH was also determined. In both cases, it was found that low concentrations of AgNPs (20 ppm) caused a significant increase in the level of intracellular GSH (Fig. 5). Then, with the increase of the dose (both AgNPs and silver ions), a slight decrease in GSH content in the cells was observed. A large difference in the concentration of GSH after treatment of the cells by AgNPs or silver ions at activating concentration, i.e., 20 ppm was found in the case of the sensitive variety (Raweta).

\section{Discussion}

In recent years, an increase in the use of nanoparticles as pesticides has been found; therefore, it is of crucial importance to clarify whether and how the nanoparticles are toxic to plant cells. The presented experiments were focused on a study of the direct interaction of silver (applied in two forms, i.e., as ions and nanoparticles) with cells of wheat-one of the most popular cereals (Table 3).

Microscopic observations of in vitro wheat cells incubated with nanoparticles (AgNPs) or silver ions showed morphological changes dependent on the concentration of stressors. Naturally elongated callus cells in the presence of nanoparticles or silver ions underwent swelling and significant reduction of length; however, no differences
(A)

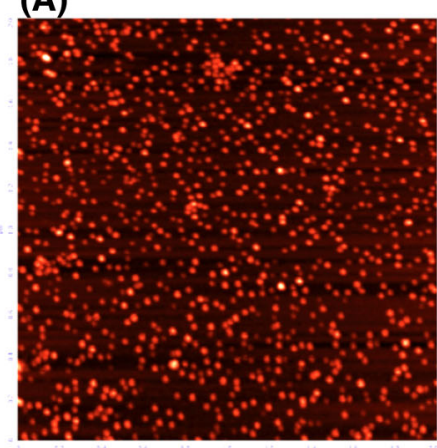

(B)

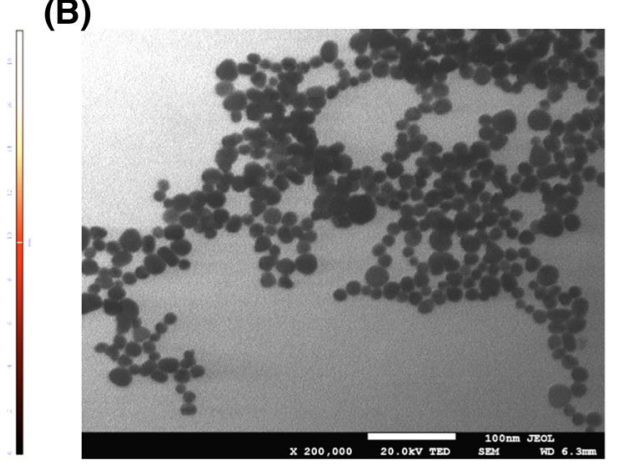

(C)

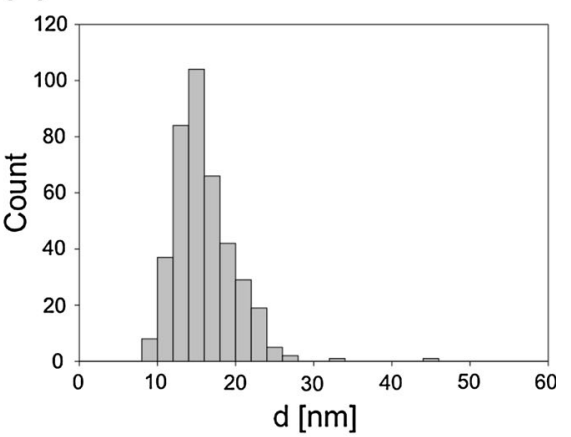

Fig. 1 Images of the obtained nanoparticles: a AFM image of monolayer of AgNPs deposited on PHA-covered mica $(2 \mu \mathrm{m} \times 2 \mu \mathrm{m}), \mathbf{b}$ TEM microphotography of AgN deposited on copper grid (bar corresponds to $100 \mathrm{~nm}$ ), $\mathbf{c}$ the size distribution of AgNPs obtained from TEM 
Fig. 2 Images of callus cells (Parabola and Raweta) cultured on control media (0) and supplemented with AgNPs or $\mathrm{AgNO}_{3}$ for $24 \mathrm{~h}(40,60 \mathrm{ppm})$; observation in white light, magnification $\times 200$
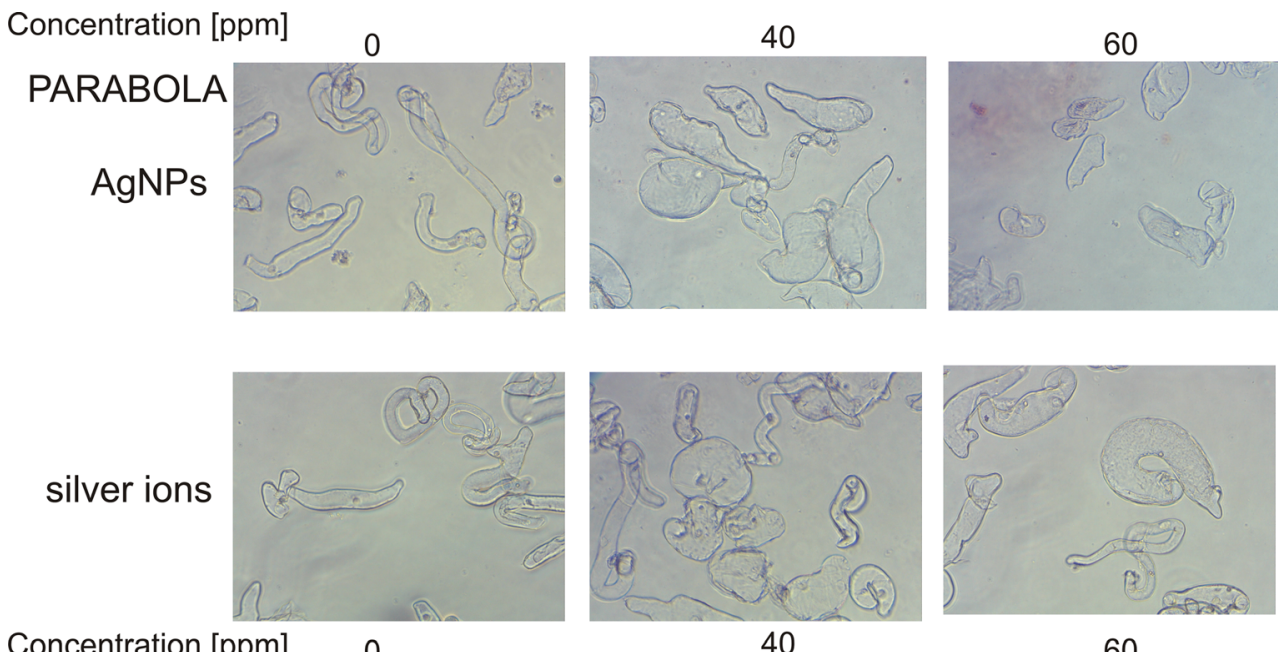

40

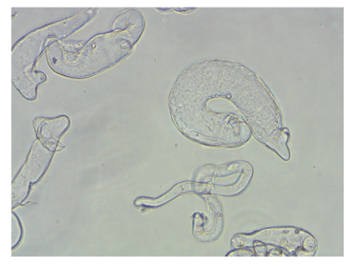

60
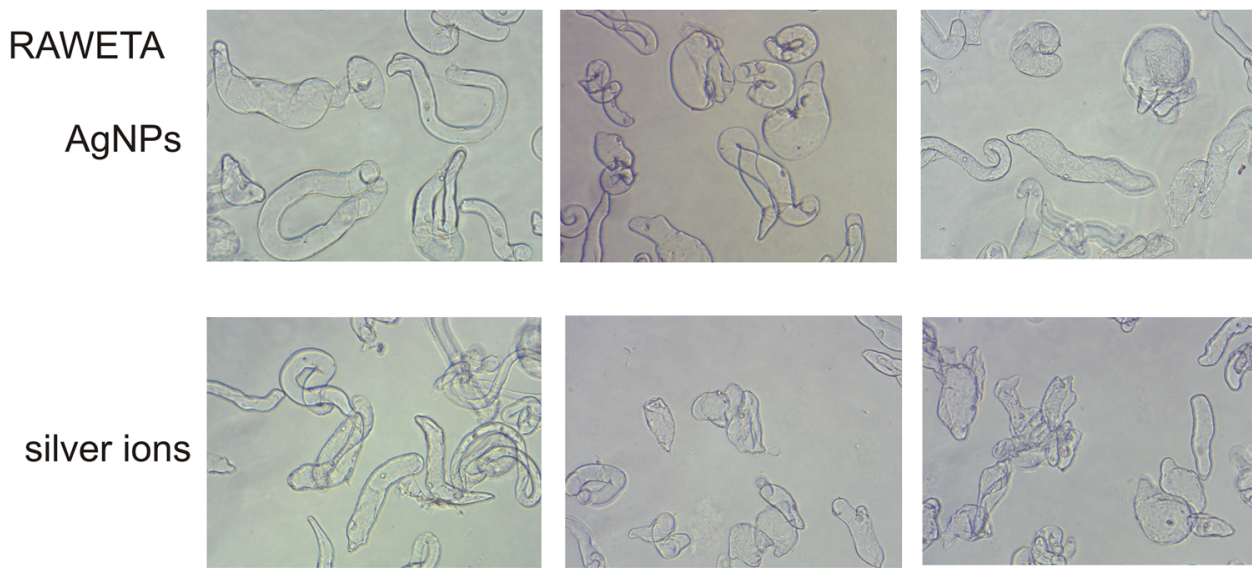

between wheat varieties were noticed. Such visible structural deformations indicate that silver used in both forms may act as the stress factor. Changes in the cell structure induced by AgNPs and silver ions, added at similar concentrations into the culture solution, were found earlier by Yin et al. (2011) in Lolium multiflorum seedlings.

Changes of MDA concentration as the effect of a modification of membrane structures indicate a stress action. MDA content is generally the accepted indicator of the degree of membrane lipid peroxidation under ROS action, and it is assumed that the magnitude of MDA changes may indicate about plant resistance to stressors (Møller et al. 2007; Selote and Khanna-Chopra 2006). Regardless of the stressor, a greater change in the MDA level was found for the sensitive Raweta variety in comparison to Parabola, which confirms its sensitivity. An increase of MDA level in plant tissues under the influence of metal nanoparticles was found earlier inter alia in rice (Oryza sativa L.) (Shaw and Hossain 2013), mung bean (Vigna radiata L.) (Nair and Chung 2015) and wheat ( $T$. aestivum L.) (Dimkpa et al. 2012). The application of both studied silver forms resulted in an increase of MDA concentration in the examined wheat varieties. A greater increase of MDA content was noticed for sensitive Raweta that was similar for both applied stressors. In cells of tolerant Parabola, a rise of MDA level was smaller (in comparison to Raweta) with larger effects caused by silver ions (at concentrations of 40 and $60 \mathrm{ppm}$ ). This may suggest a structural/chemical relationship between the membranes of plant cells and nanoparticles adsorbed on their surface.

As it was found for Parabola and Raweta seedlings cultured in control conditions, the membranes of the tolerant variety contained a larger fraction of unsaturated fatty acids in comparison to the sensitive one (Filek et al. 2012). Similar differences in membrane saturation between investigated varieties developed under control in vitro conditions were inferred indirectly from variations of MDA content: greater in Raweta than in Parabola cells.

Changes in the activity of antioxidative enzymes caused by silver applied during calli culture point to the occurrence of oxidative stress and ROS action resulting in lipid peroxidation. Superoxide dismutases (SOD) are responsible for catalyzing dismutation of superoxide radical to $\mathrm{O}_{2}$ and $\mathrm{H}_{2} \mathrm{O}_{2}$ (Bowler et al. 1992). An increased activity of 

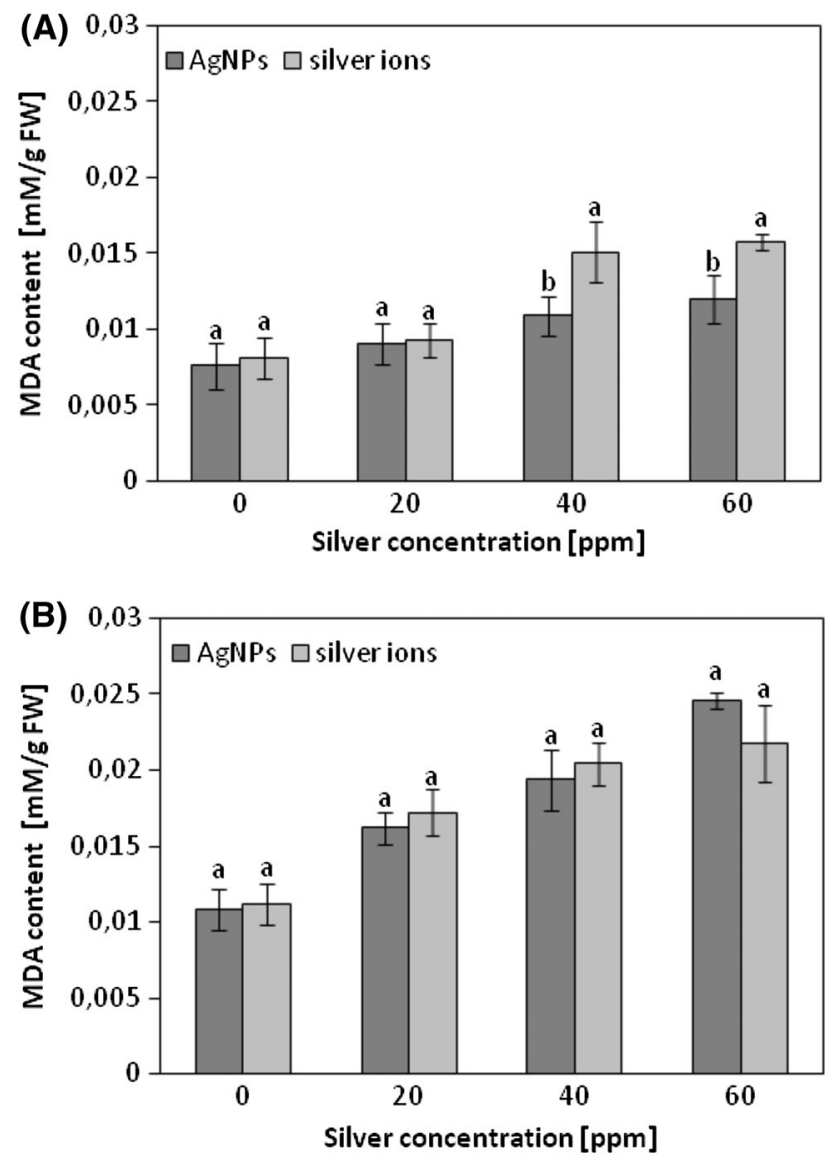

Fig. 3 Content of malondialdehyde (MDA) in callus cells of Parabola (a) and Raweta (b) after culture on control media (0) and after $24 \mathrm{~h}$ exposure to silver nanoparticles (AgNPs) and silver ions $\left(\mathrm{AgNO}_{3}\right)$ of different concentrations. Values are mean \pm SE. Different letters indicate significant $(p<0.05)$ differences between treatments

superoxide dismutase was registered in cucumber $(\mathrm{Cu}$ cumis sativus L.) (Kim et al. 2012) and rice (O. sativa L.) (Shaw and Hossain 2013) under the influence of metal oxide nanoparicles. The results presented here showed that treatment of plant cells with both AgNPs and $\mathrm{Ag}^{+}$did not cause a statistically significant change in SODs activity in the tolerant variety. This may suggest that in the tolerant variety, other antioxidants (i.e., non-enzymatic, such as glutathione) may be involved in cell protection, and/or, nanoparticle concentrations used in the present study were not stressful for this variety. On the other hand, in sensitive Raweta, changes in SOD activity were dependent on silver concentration. The increased SODs activity at lower doses of both types of silver forms indicates a mobilization of enzymatic antioxidant systems under these conditions. A decreased activity observed at the highest tested $\mathrm{Ag}^{+}$ concentration implies a possibility of damage of the SOD protein structure by excessive level of generated ROS (Kang et al. 2007).
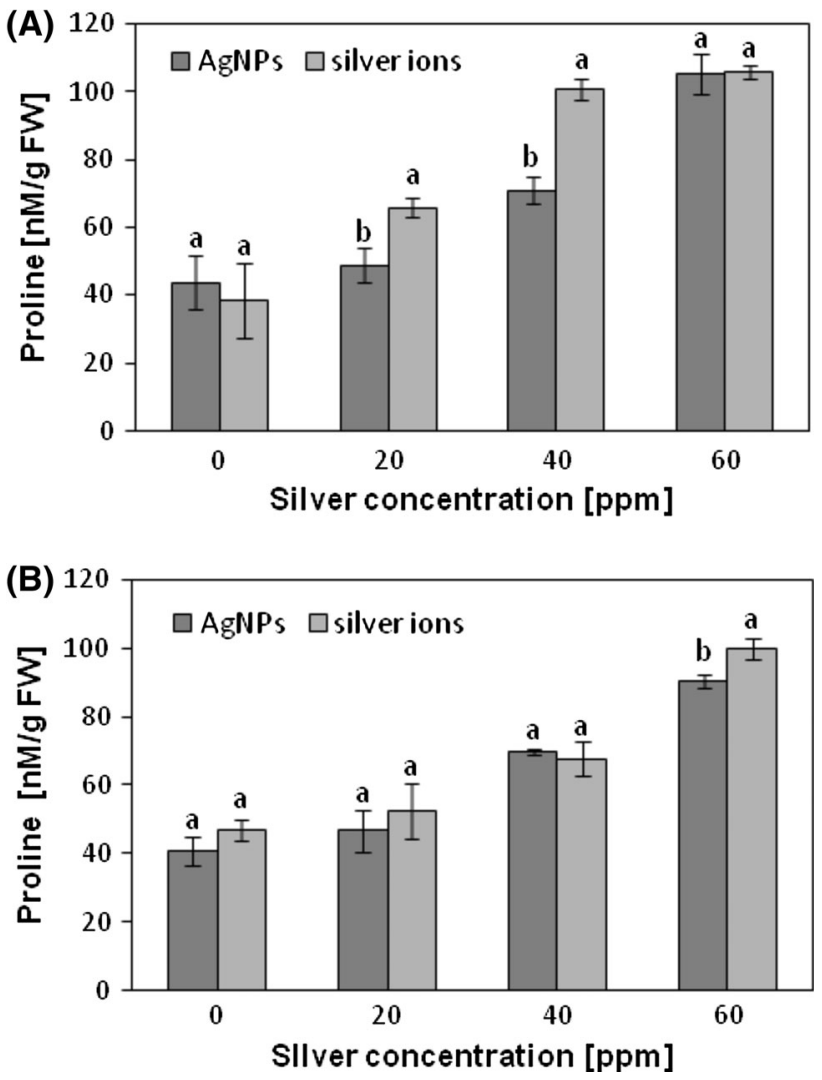

Fig. 4 Proline concentrations in callus cells of Parabola (a) and Raweta (b) after culture on control media (0) and after $24 \mathrm{~h}$ exposure to silver nanoparticles (AgNPs) and silver ions $\left(\mathrm{AgNO}_{3}\right)$ of different concentrations. Values are mean \pm SE. Different letters indicate significant $(p<0.05)$ differences between treatments

Both, CAT and POX, are arrays responsible for the decomposition of hydrogen peroxide to water and oxygen. The largest reduction of CAT activity (about $95 \%$ in comparison to control) observed at the highest concentration of nanoparticles and silver ions confirms that at this concentration (thus at corresponding amount of generated ROS), the synthesis of this group of enzymes is inhibited (de Carvalho 2008; Lee et al. 2012). The research conducted by Dimkpa et al. (2012) showed that treatment of wheat cells with $\mathrm{ZnO}$ resulted in changes in the activity of catalase similar to those found in the present study. The activity of POX distinguished the tested varieties. The increased POX activity in the sensitive variety shows that at higher concentrations of $\mathrm{AgNPs}$ and $\mathrm{AgNO}_{3}$, a group of these enzymes was activated. The rise of POX activity after treatment with metal oxide nanoparticles $(\mathrm{CuO})$ was also observed in C. sativus (Kim et al. 2012). In the case of the tolerant variety, we found that POX activity decreased; however these changes were larger under stress caused by silver ions. The observed variations in the activity of antioxidant enzymes in tested wheat varieties allow to conclude that the system deactivation of reactive oxygen 
Table 2 Antioxidant activities ( $S O D$ superoxide dismutase, $P O X$ peroxidase, $C A T$ catalase) in callus cells of parabola after culture on control media (0) and after $24 \mathrm{~h}$ exposure to silver nanoparticles $(\mathrm{AgN})$ and silver ions $\left(\mathrm{AgNO}_{3}\right)$ of different concentrations

\begin{tabular}{llll}
\hline Concentration $(\mathrm{ppm})$ & SOD $(\mathrm{U} / \mathrm{mg}$ of proteins) & POX $(\mathrm{U} / \mathrm{mg}$ of proteins) & CAT $(\mathrm{U} / \mathrm{mg}$ of proteins) \\
\hline $\mathrm{AgN}$ & & & \\
0 & $0.9716 \pm 0.0408^{\mathrm{a}}$ & $2.1206 \pm 0.0563^{\mathrm{a}}$ & $0.00219 \pm 0.00001^{\mathrm{a}}$ \\
20 & $0.9050 \pm 0.0544^{\mathrm{a}}$ & $2.0210 \pm 0.0378^{\mathrm{a}}$ & $0.00032 \pm 0.00007^{\mathrm{b}}$ \\
40 & $0.8981 \pm 0.0136^{\mathrm{a}}$ & $1.5163 \pm 0.0559^{\mathrm{b}}$ & $0.00014 \pm 0.00001^{\mathrm{b}}$ \\
60 & $0.8931 \pm 0.0408^{\mathrm{a}}$ & $1.7606 \pm 0.0171^{\mathrm{b}}$ & $0.00029 \pm 0.00014^{\mathrm{b}}$ \\
$\mathrm{AgNO}_{3}$ & & & \\
0 & $0.8408 \pm 0.0816^{\mathrm{a}}$ & $2.3775 \pm 0.1358^{\mathrm{a}}$ & $0.00223 \pm 0.00003^{\mathrm{a}}$ \\
20 & $0.8306 \pm 0.0272^{\mathrm{a}}$ & $1.9271 \pm 0.0954^{\mathrm{b}}$ & $0.00021 \pm 0.00003^{\mathrm{b}}$ \\
40 & $1.0031 \pm 0.1224^{\mathrm{a}}$ & $1.5539 \pm 0.1176^{\mathrm{c}}$ & $0.00026 \pm 0.00012^{\mathrm{b}}$ \\
60 & $0.9087 \pm 0.0408^{\mathrm{a}}$ & $1.4639 \pm 0.1319^{\mathrm{c}}$ & $0.00013 \pm 0.00011^{\mathrm{b}}$ \\
\hline
\end{tabular}

Values are mean \pm SE. Different letters indicate significant $(p<0.05)$ differences between treatments
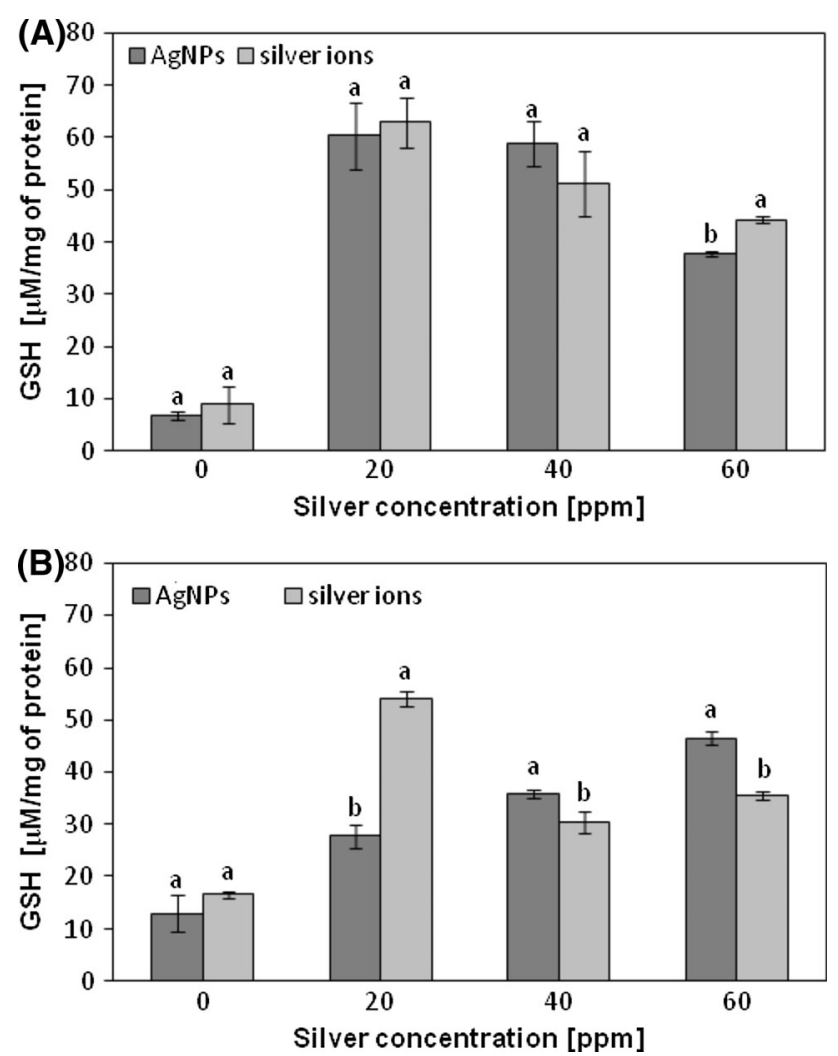

Fig. 5 Concentration of intracellular GSH in calli of Parabola (a) and Raweta (b) treated for $24 \mathrm{~h}$ with $\mathrm{AgNPs}$ or $\mathrm{AgNO}_{3}$. Values are mean \pm SE. Different letters indicate significant $(p<0.05)$ differences between treatments

species was more activated in the sensitive than in the tolerant variety.

The level of intracellular glutathione (GSH) is accepted as an universal marker of oxidative stress in plants (Apel and Hirt 2004), but this nonenzymatic antioxidant is also responsible for resistance to xenobiotics, sulfur signaling status, tolerance to heavy metals or defense against pathogens (Tausz 2001). The role of GSH as a protectant against ROS was confirmed here by an increase of GSH levels in callus cells of both genotypes exposed to AgNPs and $\mathrm{AgNO}_{3}$ at all used concentrations. An increased content of reduced glutathione after treatment with metal ions $(\mathrm{CuO})$ was also recorded by Shaw and Hossain (2013). Greater changes of GSH content in the tolerant variety in comparison to the sensitive one showed that this nonenzymatic compound was the main antioxidant, the synthesis of which was activated in the tolerant variety in conditions of oxidative stress induced by the presence of silver in both forms. However, in the sensitive variety, a smaller increase in GSH level with simultaneous activation of antioxidant enzymes (especially of SOD and POX) can suggest that in the defense mechanism, both enzymatic and nonenzymatic antioxidants are operating.

The interesting observation is the rise of proline content in wheat cells treated by both silver forms. Proline is one of the osmoprotectants synthesized in plants in response to stress conditions. So far, it has been shown that under such stresses as drought (Grzesiak et al. 2013), salt (Kumar et al. 2008), high and low temperatures (Babu and Devraj 2008), heavy metals (Theriappan et al. 2011), mineral deficiency, UV (Saradhi et al. 1995) and biotic stress (Haudecoeur et al. 2009), the proline concentration increased often to values several times higher than that observed in control conditions. Independently of the osmoprotective role of proline, some studies have shown that this molecule can help maintain redox balance in cells (Mohammadkhani and Heidari 2008). Involving of proline in antioxidant defense and its participation in the deactivation of the hydroxyl radical ( $\mathrm{OH})$ was indicated by Chen and Dickman (2005) and Sankar et al. (2007) as well as in stabilization of singlet oxygen $\left({ }^{1} \mathrm{O}_{2}\right)$ (Matysik et al. 2002). However, the results of the recent studies by Signorelli et al. (2013) suggest that this amino acid plays no significant role in antioxidant processes.

The experimental results performed on in vitro wheat cells revealed a correlation between the increased 
Table 3 Antioxidant activities ( $S O D$ superoxide dismutase, $P O X$ peroxidase, $C A T$ catalase) in callus cells of raweta after culture on control media ( 0$)$ and after $24 \mathrm{~h}$ exposure to silver nanoparticles $(\mathrm{AgN})$ and silver ions $\left(\mathrm{AgNO}_{3}\right)$ of different concentrations

\begin{tabular}{llll}
\hline Concentration $(\mathrm{ppm})$ & SOD $(\mathrm{U} / \mathrm{mg}$ of proteins) & POX $(\mathrm{U} / \mathrm{mg}$ of proteins) & CAT $(\mathrm{U} / \mathrm{mg}$ of proteins) \\
\hline $\mathrm{AgN}$ & & & \\
0 & $0.8475 \pm 0.0679^{\mathrm{b}}$ & $1.1426 \pm 0.0807^{\mathrm{b}}$ & $0.00198 \pm 0.00007^{\mathrm{a}}$ \\
20 & $0.8646 \pm 0.0689^{\mathrm{b}}$ & $1.2056 \pm 0.0041^{\mathrm{b}}$ & $0.00032 \pm 0.00013^{\mathrm{b}}$ \\
40 & $1.1320 \pm 0.0519^{\mathrm{a}}$ & $1.0572 \pm 0.0559^{\mathrm{b}}$ & $0.00028 \pm 0.00012^{\mathrm{c}}$ \\
60 & $1.1382 \pm 0.0272^{\mathrm{a}}$ & $1.3632 \pm 0.1216^{\mathrm{a}}$ & $0.00084 \pm 0.00008^{\mathrm{d}}$ \\
$\mathrm{AgNO}_{3}$ & & \\
0 & $0.7625 \pm 0.0100^{\mathrm{c}}$ & $1.1468 \pm 0.1266^{\mathrm{b}}$ & $0.00190 \pm 0.00001^{\mathrm{a}}$ \\
20 & $1.0054 \pm 0.0952^{\mathrm{b}}$ & $1.2514 \pm 0.1355^{\mathrm{b}}$ & $0.00023 \pm 0.00004^{\mathrm{b}}$ \\
40 & $1.2303 \pm 0.0136^{\mathrm{a}}$ & $1.5927 \pm 0.1536^{\mathrm{a}}$ & $0.00007 \pm 0.00002^{\mathrm{b}}$ \\
60 & $0.9110 \pm 0.0952^{\mathrm{b}}$ & $1.7002 \pm 0.0462^{\mathrm{a}}$ & $0.00010 \pm 0.00007^{\mathrm{b}}$ \\
\hline
\end{tabular}

Values are mean \pm SE. Different letters indicate significant $(p<0.05)$ differences between treatments proline content and concentration of silver (in both forms) introduced into the culture media for both studied varieties. Taking into account the morphological changes of stressed cells (swelling), it can be supposed that the enhanced proline level is involved in osmoregulation under increased metal accumulation in cells. Greater changes of proline synthesis in tolerant Parabola cells in comparison to sensitive Raweta may indicate a significant contribution of this compound in the cell protection.

\section{Conclusions}

One could state that both tested stressors may induce oxidative stress in plant cells as a consequence of the osmotic stress action. The increase of the volume of cells (observed microscopically) was connected with the rise of proline level. The differences in membrane peroxidation confirm the important role of lipid composition in the distinction of both types of wheat cells: sensitive and tolerant in terms of susceptibility to silver stress. Sensitive and resistant varieties can also be distinguished on the basis of activation of antioxidative defense mechanisms. In calli of the tolerant variety (Parabola) only the nonenzymatic antioxidant system was activated, while in Raweta (sensitive), both enzymatic and non-enzymatic pathways were activated in the defense against ROS. The obtained results have demonstrated that exposure of callus cells to silver nanoparticles or silver ions may cause similar results.

Author contribution statement $\mathrm{AB}$ and $\mathrm{BK}$ designed the research; $\mathrm{AB}, \mathrm{BK}$ and $\mathrm{MO}$ conducted the research; $\mathrm{AB}$ and $\mathrm{BK}$ analyzed the data; $\mathrm{AB}$ and $\mathrm{BK}$ wrote the paper; $\mathrm{AB}$ and BK had primary responsibility for the final content. All authors have read and approved the final manuscript.
Open Access This article is distributed under the terms of the Creative Commons Attribution 4.0 International License (http://crea tivecommons.org/licenses/by/4.0/), which permits unrestricted use, distribution, and reproduction in any medium, provided you give appropriate credit to the original author(s) and the source, provide a link to the Creative Commons license, and indicate if changes were made.

\section{References}

Aebi H (1984) Catalase in vitro. Methods Enzymol 105:121-126. doi:10.1016/S0076-6879(84)05016-3

Apel K, Hirt H (2004) Reactive oxygen species: metabolism, oxidative stress, and signal transduction. Annu Rev Plant Biol 55:373-399. doi:10.1146/annurev.arplant.55.031903.141701

Arora S, Jain J, Rajwade JM, Paknikar KM (2008) Cellular responses induced by silver nanoparticles: in vitro studies. Toxicol Lett 179(2):93-100. doi:10.1016/j.toxlet.2008.04.009

Asada K (1992) Ascorbate peroxidase: a hydrogen peroxide-scavenging enzyme in plants. Physiol Plant 85(2):235-241. doi:10. 1111/j.1399-3054.1992.tb04728.x

Atha DH, Wang H, Petersen EJ, Cleveland D, Holbrook RD, Jaruga P, Dizdaroglu M, Xing B, Nelson BC (2012) Copper oxide nanoparticle mediated DNA damage in terrestrial plant models. Environ Sci Technol 46(3):1819-1827. doi:10.1021/es202660k

Babu NR, Devraj VR (2008) High temperature and salt stress response in French bean (Phaseolus vulgaris). Aust J Crop Sci 2:40-48

Bali R, Harris AT (2010) Biogenic synthesis of Au nanoparticles using vascular plants. Ind Eng Chem Res 49(24):12762-12772. doi:10.1021/ie101600m

Barbasz A, Oćwieja M, Barbasz J (2015) Cytotoxic activity of highly purified silver nanoparticles sol against cells of human immune system. Appl Biochem Biotechnol 176(3):817-834. doi:10.1007/ s12010-015-1613-3

Bates LS, Waldron RP, Teare ID (1973) Rapid determination of free proline for water stress studies. Plant Soil 39:205-208. doi:10. 1007/BF00018060

Bowler C, Montagu MV, Inze D (1992) Superoxide dismutase and stress tolerance. Annu Rev Plant Biol 43(1):83-116. doi:10. 1146/annurev.pp.43.060192.000503

Bradford MM (1976) A rapid and sensitive method for the quantitation of microgram quantities of protein utilizing the 
principle of protein-dye binding. Anal Biochem 72:248-254. doi:10.1016/0003-2697(76)90527-3

Chen C, Dickman MB (2005) Poline suppresses apoptosis in the fungal pathogen Colletotrichum trifolli. Proc Natl Acad Sci USA 102:3459-3464. doi:10.1073/pnas.0407960102

Dadosh T (2009) Synthesis of uniform silver nanoparticles with a controllable size. Mater Lett 63:2236-2238. doi:10.1016/j. matlet.2009.07.042

de Carvalho MHC (2008) Drought stress and reactive oxygen species. Plant Signal Behav 3(3):156-165

Dhindsa RS, Plumb-Dhinds P, Thorpe TA (1981) Leaf senescence correlated with increased levels of membrane permeability and lipid peroxidation, and decreased levels of superoxide dismutase and catalase. J Exp Bot 32:93-101. doi:10.1093/jxb/32.1.93

Dimkpa CO, McLean JE, Latta DE, Manangón E, Britt DW, Johnson WP, Boyanow ML, Anderson AJ (2012) $\mathrm{CuO}$ and $\mathrm{ZnO}$ nanoparticles: phytotoxicity, metal speciation, and induction of oxidative stress in sand-grown wheat. J Nanopart Res 14(9):1-15. doi:10.1007/s11051-012-1125-9

Dutta A, Dolui SK (2011) Tannic acid assisted one step synthesis route for stable colloidal dispersion of nickel nanostructures. Appl Surf Sci 257:6889-6896. doi:10.1016/j.apsusc.2011.03.025

Ellman GL (1958) A colorimetric method of determining of low concentrations of mercaptans. Arch Biochem Biophys 74(2):443-450. doi:10.1016/0003-9861(58)90014-6

Elstner EF, Osswald W (1994) Mechanisms of oxygen activation during plant stress. Proc R Soc Edinb Sect B Biol Sci 102:131-154. doi:10.1017/S0269727000014068

Filek M, Zembala M, Hartikainen H, Miszalski Z, Kornaś A, Wietecka-Posłuszny R (2009) Changes in wheat plastid membrane properties induced by cadmium and selenium in presence/ absence of 2,4-dichlorophenoxyacetic acid. Plant Cell, Tissue Organ Cult 96:19-28

Filek M, Walas S, Mrowiec H, Rudolphy-Skórska E, Sieprawska A, Biesaga-Kościelniak J (2012) Membrane permeability and microand macroelement accumulation in spring wheat cultivars during the short-term effect of salinity-and PEG-induced water stress. Acta Physiol Plant 34(3):985-995. doi:10.1007/s11738-011-0895-5

Foldbjerg R, Dang DA, Autrup H (2011) Cytotoxicity and genotoxicity of silver nanoparticles in the human lung cancer cell line, A549. Arch Toxicol 85(7):743-750. doi:10.1007/s00204-0100545-5

Foyer CH, Noctor G (2000) Oxygen processing in photosynthesis: regulation and signalling. Tansley Review No. 112. New Phytol 146:359-388. doi:10.1046/j.1469-8137.2000.00667.x

Franklin NM, Rogers NJ, Apte SC, Batley GE, Gadd GE, Casey PS (2007) Comparative toxicity of nanoparticulate $\mathrm{ZnO}$, bulk $\mathrm{ZnO}$, and $\mathrm{ZnCl}_{2}$ to a freshwater microalga (Pseudokirchneriella subcapitata): the importance of particle solubility. Environ Sci Technol 41(24):8484-8490. doi:10.1021/es071445r

Godin B, Sakamoto JH, Serda RE, Grattoni A, Bouamrani A (2010) Emerging applications of nanomedicine for the diagnosis and treatment of cardiovascular diseases. Trends Pharmacol Sci 31:199-205. doi:10.1016/j.tips.2010.01.003

Gorczyca A, Warszewska M, Kasprowicz M, Niemiec M, Pociecha E (2013) Nanosilver: safe or dangerous plant protection? Acta Biol Crac Ser Bot 2(55):16

Gorczyca A, Pociecha E, Kasprowicz M, Niemiec M (2015) Effect of nanosilver in wheat seedlings and Fusarium culmorum culture systems. Eur J Plant Pathol 142(2):251-261. doi:10.1007/ s10658-015-0608-9

Grzesiak M, Filek M, Barbasz A, Kreczmer B, Hartikainen H (2013) Relationships between polyamines, ethylene, osmoprotectants and antioxidant enzymes activities in wheat seedlings after shortterm PEG-and NaCl-induced stresses. Plant Growth Regul 69(2):177-189. doi:10.1007/s10725-012-9760-9
Harris AT, Bali R (2008) On the formation and extent of uptake of silver nanoparticles by live plants. J Nanopart Res 10(4):691-695. doi:10.1007/s11051-007-9288-5

Haudecoeur E, Planamente S, Cirou A, Tannieres M, Shelp BJ, Moréra S, Faure D (2009) Proline antagonizes GABA-induced quenching of quorum-sensing in Agrobacterium tumefaciens. Proc Natl Acad Sci 106(34):14587-14592. doi:10.1073/pnas. 0808005106

Huang H, Yang X (2005) One-step, shape control synthesis of gold nanoparticles stabilized by 3-thiopheneacetic acid. Coll Surf A Physicochem Eng Asp 255(1):11-17. doi:10.1016/j.colsurfa. 2004.12.020

Iravani S (2011) Green synthesis of metal nanoparticles using plants. Green Chem 13(10):2638-2650. doi:10.1039/C1GC15386B

Kang S, Pinault M, Pfefferle LD, Elimelech M (2007) Single-walled carbon nanotubes exhibit strong antimicrobial activity. Langmuir 23(17):8670-8673. doi:10.1021/la701067r

Kim JS, Kuk E, Yu KN, Kim JH, Park SJ, Lee HJ, Cho MH (2007) Antimicrobial effects of silver nanoparticles. Nanomed Nanotechnol Biol Med 3(1):95-101. doi:10.1016/j.nano.2006.12.001

Kim S, Choi JE, Choi J, Chung KH, Park K, Yi J, Ryu DY (2009) Oxidative stress-dependent toxicity of silver nanoparticles in human hepatoma cells. Toxicol In Vitro 23(6):1076-1084. doi:10.1016/j.tiv.2009.06.001

Kim S, Lee S, Lee I (2012) Alteration of phytotoxicity and oxidant stress potential by metal oxide nanoparticles in Cucumis sativus. Water Air Soil Pollut 223(5):2799-2806. doi:10.1007/s11270011-1067-3

Kohl Y, Kaiser C, Bost W, Stracke F, Fournelle M, Wischke C, Thielecke H, Lendlein A, Kratz K, Lemor R (2011) Preparation and biological evaluation of multifunctional PLGA-nanoparticles designed for photoacoustic imaging. Nanomed Nanotechnol Biol Med 7(2):228-237. doi:10.1016/j.nano.2010.07.006

Kokura S, Handa O, Takagi T, Ishikawa T, Naito Y, Yoshikawa T (2010) Silver nanoparticles as a safe preservative for use in cosmetics. Nanomed Nanotechnol Biol Med 6(4):570-574. doi:10.1016/j.nano.2009.12.002

Kreuter J, Gelperina S (2008) Use of nanoparticles for cerebral cancer. Tumori 94:271-277

Kujda M, Oćwieja M, Adamczyk Z, Bocheńska O, Graś G, Kozik A, Barbasz J (2015) Charge stabilized silver nanoparticles applied as antibacterial agents. J Nanosci Nanotechnol 15:3574-3583. doi:10.1166/jnn.2015.9727

Kumar V, Shriram V, Nikam TD, Jawali N, Shitole MG (2008) Sodium chloride-induced changes in mineral nutrients and proline accumulation in indica rice cultivars differing in salt tolerance. J Plant Nutr 31(11):1999-2017. doi:10.1080/ 01904160802403466

Kumari M, Mukherjee A, Chandrasekaran N (2009) Genotoxicity of silver nanoparticles in Allium cepa. Sci Total Environ 407(19):5243-5246. doi:10.1016/j.scitotenv.2009.06.024

Lee CW, Mahendra S, Zodrow K, Li D, Tsai YC, Braam J, Alvarez PJ (2010) Developmental phytotoxicity of metal oxide nanoparticles to Arabidopsis thaliana. Environ Toxicol Chem 29(3):669-675. doi:10.1002/etc.58

Lee WM, Kwak JI, An YJ (2012) Effect of silver nanoparticles in crop plants Phaseolus radiatus and Sorghum bicolor: media effect on phytotoxicity. Chemosphere 86(5):491-499. doi:10. 1016/j.chemosphere.2011.10.013

Lück H (1962) Methoden der enzymatisch en analyse. Verl Chem. doi:10.1002/pauz.19750040306

Lushchak VI (2011) Environmentally induced oxidative stress in aquatic animals. Aquat Toxicol 101(1):13-30. doi:10.1016/j. aquatox.2010.10.006

Marambio-Jones C, Hoek EM (2010) A review of the antibacterial effects of silver nanomaterials and potential implications for 
human health and the environment. J Nanopart Res 12(5):1531-1551. doi:10.1007/s11051-010-9900-y

Matysik J, Ali Bhalu B, Mohanty P (2002) Molecular mechanism of quenching of reactive oxygen species by proline under water stress in plants. Curr Sci 82:525-532

McCord IM, Fridovich I (1969) Superoxide dismutase an enzymatic function for erythrocuprein (hemocuprein). J Biol Chem 224:6049-6055

Meng H, Liong M, Xia T, Li Z, Ji Z, Zink JI, Nell AE (2010) Engineered design of mesoporous silica nanoparticles to deliver doxorubicin and P-glycoprotein siRNA to overcome drug resistance in a cancer cell line. ACS Nano 4(8):4539-4550. doi:10.1021/nn100690m

Miao AJ, Schwehr KA, Xu C, Zhang SJ, Luo Z, Quigg A, Santschi PH (2009) The algal toxicity of silver engineered nanoparticles and detoxification by exopolymeric substances. Environ Pollut 157(11):3034-3041. doi:10.1016/j.envpol.2009.05.047

Miller G, Suzuki N, Ciftci-Yilmaz S, Mittler R (2010) Reactive oxygen species homeostasis and signalling during drought and salinity stresses. Plant, Cell Environ 33(4):453-467. doi:10. 1111/j.1365-3040.2009.02041.x

Mohammadkhani N, Heidari R (2008) Drought-induced accumulation of soluble sugars and proline in two maize varieties. World Appl Sci J 3(3):448-453

Møller IM, Jensen PE, Hansson A (2007) Oxidative modifications to cellular components in plants. Annu Rev Plant Biol 58:459-481. doi:10.1146/annurev.arplant.58.032806.103946

Murashige T, Skoog F (1962) A revised medium for rapid growth and bio assays with tobacco tissue cultures. Physiol Plant 15(3):473-497. doi:10.1111/j.1399-3054.1962.tb08052.x

Mushtaq YK (2011) Effect of nanoscale $\mathrm{Fe}_{3} \mathrm{O}_{4}, \mathrm{TiO}_{2}$ and carbon particles on cucumber seed germination. J Environ Sci Health, Part A 46(14):1732-1735. doi:10.1080/10934529.2011.633403

Nair PMG, Chung IM (2015) Physiological and molecular level studies on the toxicity of silver nanoparticles in germinating seedlings of mung bean (Vigna radiata L.). Acta Physiol Plant 37(1):1-11. doi:10.1007/s11738-014-1719-1

Navarro E, Piccapietra F, Wagner B, Marconi F, Kaegi R, Odzak N, Behra R (2008) Toxicity of silver nanoparticles to Chlamydomonas reinhardtii. Environ Sci Technol 42(23):8959-8964. doi:10.1021/es $801785 \mathrm{~m}$

Nekrasova GF, Ushakova OS, Ermakov AE, Uimin MA, Byzov IV (2011) Effects of copper(II) ions and copper oxide nanoparticles on Elodea densa Planch. Russ J Ecol 42(6):458-463. doi:10. 1134/S1067413611060117

Noctor G, Foyer CH (1998) Ascorbate and glutathione: keeping active oxygen under control. Annu Rev Plant Biol 49(1):249-279. doi:10.1146/annurev.arplant.49.1.249

Oćwieja M, Adamczyk Z (2014) Monolayers of silver nanoparticles obtained by chemical reduction methods. Surf Innov 2(3):160-172. doi:10.1680/si.13.00042

Oćwieja M, Adamczyk Z, Morga M, Michna A (2011) High density silver nanoparticle monolayers produced by colloid self-assembly on polyelectrolyte supporting layers. J Coll Interface Sci 364:39-48. doi:10.1016/j.jcis.2011.07.059

Pal S, Tak YK, Song JM (2007) Does the antibacterial activity of silver nanoparticles depend on the shape of the nanoparticle? A study of the gram-negative bacterium Escherichia coli. Appl
Environ Microbiol 73(6):1712-1720. doi:10.1128/AEM.0221806

Raveendran P, Fu J, Wallen SL (2003) Completely "green" synthesis and stabilization of metal nanoparticles. J Am Chem Soc 125(46):13940-13941. doi:10.1021/ja029267j

Sankar B, Jaleel CA, Manivannan P, Kishorekumar A, Somasundram R, Panneerselvam R (2007) Drought-induced biochemical modifications and proline metabolism in Abelmoschus esculentus (L.). Moench Acta Bot Croat 66:43-56

Saradhi PP, AliaArora S, Prasad KVSK (1995) Proline accumulates in plants exposed to UV radiation and protects them against UVinduced peroxidation. Biochem Biophys Res Commun 209(1):1-5. doi:10.1006/bbrc.1995.1461

Selote DS, Khanna-Chopra R (2006) Drought acclimation confers oxidative stress tolerance by inducing co-ordinated antioxidant defense at cellular and subcellular level in leaves of wheat seedlings. Physiol Plant 127(3):494-506. doi:10.1111/j.13993054.2006.00678.x

Shaw AK, Hossain Z (2013) Impact of nano-CuO stress on rice (Oryza sativa L.) seedlings. Chemosphere 93(6):906-915. doi:10.1016/j.chemosphere.2013.05.044

Shi J, Abid AD, Kennedy IM, Hristova KR, Silk WK (2011) To duckweeds (Landoltia punctata), nanoparticulate copper oxide is more inhibitory than the soluble copper in the bulk solution. Environ Pollut 159(5):1277-1282. doi:10.1016/j.envpol.2011.01.028

Signorelli S, Arellano JB, Melø TB, Borsani O, Monza J (2013) Proline does not quench singlet oxygen: evidence to reconsider its protective role in plants. Plant Physiol Biochem 64:80-83. doi:10.1016/j.plaphy.2012.12.017

Singh M, Singh S, Prasad S, Gambhir IS (2008) Nanotechnology in medicine and antibacterial effect of silver nanoparticles. Dig J Nanomater Biostruct 3(3):115-122

Sivaraman SK, Elango I, Kumar S, Santhanam V (2009) A green protocol for room temperature synthesis of silver nanoparticles in seconds. Curr Sci 97:1055-1059

Sivaraman SK, Kumar S, Santhanam V (2010) Room-temperature synthesis of gold nanoparticles-Size-control by slow addition. Gold Bull 43:275-286. doi:10.1007/BF03214997

Tausz M (2001) The role of glutathione in plant response and adaptation to natural stress. In: Significance of glutathione to plant adaptation to the environment. Plant Ecophysiol 2:101-122. doi:10.1007/0-306-47644-4_5

Theriappan P, Gupta AK, Dhasarrathan P (2011) Accumulation of proline under salinity and heavy metal stress in Cauliflower seedlings. J Appl Sci Environ Manag. doi:10.4314/jasem.v15i2. 68497

Tiede K, Boxall AB, Tear SP, Lewis J, David H, Hassellöv M (2008) Detection and characterization of engineered nanoparticles in food and the environment. Food Addit Contam 25(7):795-821. doi:10.1080/02652030802007553

Vannini C, Domingo G, Onelli E, De Mattia F, Bruni I, Marsoni M, Bracale M (2014) Phytotoxic and genotoxic effects of silver nanoparticles exposure on germinating wheat seedlings. J Plant Physiol 171(13):1142-1148. doi:10.1016/j.jplph.2014.05.002

Yin L, Cheng Y, Espinasse B, Colman BP, Auffan M, Wiesner M, Bernhardt ES (2011) More than the ions: the effects of silver nanoparticles on Lolium multiflorum. Environ Sci Technol 45(6):2360-2367. doi:10.1021/es103995x 